\title{
Status of the genus Eichlerago (Labiatae)
}

\author{
Barry J. Conn
}

\begin{abstract}
Conn, Barry J. (National Herbarium of New South Wales, Royal Botanic Gardens, Sydney, NSW, Australia 2000). Status of the genus Eichlerago (Labiatae). Telopea 4(4): 649-651. Eichlerago is reduced to a synonym of Prostanthera and the new combination Prostanthera tysoniana (Carrick) Conn is made. This species is regarded as belonging to Prostanthera section Prostanthera. Notes on the habitat, distribution and conservation status are included.
\end{abstract}

\section{Introduction}

Eichlerago was described by Carrick (1977) as a new genus of the Lamiaceae, with close affinities to Prostanthera. He concluded that the genus was sufficiently distinct from other labiate genera to be placed in his new monotypic tribe Eichleragineae (within the subfamily Prostantheroideae sensu Briquet 1895). However, the features that Carrick used to distinguish this genus from Prostanthera are either plesiomorphic or (it is believed) incorrectly interpreted.

The infrafamilial classification used in this paper is based on that of Bentham in Bentham \& Hooker (1876), as modified by Erdtman (1945). Hence, the Prostantheroideae sensu Briquet (1895) is referred to as the tribe Prostanthereae sensu Bentham in Bentham \& Hooker (1876), of the subfamily Lamioideae sensu Erdtman (1945).

\section{Discussion of Characters}

Carrick concluded that the shape of the corolla in Eichlerago could be used to distinguish this genus from Prostanthera. However, contrary to his interpretation, the 3-lobed abaxial (lower) corolla lip in Eichlerago is typical of most species of Prostanthera (particularly in Prostanthera section Prostanthera. Of the fruiting characters that Carrick regarded as diagnostic, only the reduced distal lobing is apomorphic. However, this condition is a convergence that is also found in Prostanthera queenslandica. The other fruiting characters that he used include 'fruits dry' and 'fruits indehiscent'. The 'dry' rather than fleshy, fruit condition is a plesiomorphy, characteristic of all Labiatae. It is not known whether the fruits of Eichlerago are indehiscent or dehiscent. It is possible that they are a foraminose schizocarp, not dissimilar to those of the Prostanthereae (Conn 1984). Finally, Carrick regarded the position of the style as a diagnostic character. However, the terminal style is also a plesiomorphy. This character distinguishes the Prostanthereae and Ajugeae from the other Labiatae which have a gynobasic style (Conn 1984, Sharma \& Singh 1982).

In an evaluation of relationships within the tribe Prostanthereae (Labiatae), Eichlerago and Prostanthera formed a clade characterised by four synapomorphies (Conn, in press). These characters were: the anther connective extended into a basal appendage, or if appendage absent (in some species of Prostanthera) then regarded as a secondary loss; the anther connective cristate with triangular trichomes; the leaves aromatic, or if non-aromatic (in a few species of Prostanthera) then regarded as a 
secondary loss; and the anther lobe terminating in a basal acumen. Eichlerago and Prostanthera section Prostanthera form the sister group to Prostanthera section Klanderia. The former clade is characterised by the adaxial lip of the calyx enlarging (often significantly) as the fruit matures. Some enlargement of the calyx has been noted in fruiting material of E. tysoniana (Payne 107 \& 126).

\section{Discussion of Infratribal Classification}

Although it is premature to formally recognize infratribal groupings within the Prostanthereae, the current evaluation of the phylogeny of this tribe (Conn, in press) does not support Carrick's interpretation that all genera (apart from Eichlerago, which he placed in Eichleragineae) belong in one group (Prostanthereae sensu Carrick 1977). Within the Prostanthereae, Conn (in press) recognizes two main groups. One group (the Prostanthera clade) consists of Prostanthera (including Eichlerago and both sections of Prostanthera) and Wrixonia, with the other group (the Microcorys clade) consisting of Hemiandra, Hemigenia, Microcorys and Westringia. Therefore, there is even less support for the 'Eichleragineae' than there is for Eichlerago.

\section{Conclusion}

It is concluded that Eichlerago cannot be maintained as a distinct monotypic genus and it is here proposed that it become part of Prostanthera section Prostanthera.

\section{Taxonomy}

Prostanthera Labill., Nov. Holl. Pl. Spec. 2: 18, t. 157 (1806).

TYPE SPECIES: Prostanthera lasianthos Labill.

TYPE: 'Van-Diemen', Labillardière s.n., - (n.v.).

Eichlerago Carrick, J. Adelaide Bot. Gard. 1: 115 (1977).

TYPE SPECIES: Eichlerago tysoniana Carrick

TYPE: Tyson 25 (for details refer below).

Prostanthera tysoniana (Carrick) Conn, comb. nov.

BAsionym: Eichlerago tysoniana Carrick, J. Adelaide Bot. Gard. 1: 115, fig. 1 (1977). Holotype: Western Australia: 'Mt Narryer, Murchison River', I. Tyson 25, 1898 (PERTH); iso K.

DESCRIPTION: Refer Carrick (1977).

HaвтTAT: Open Acacia brachystachya-dominated shrubland on shallow (0.5-0.7 m deep) red sandy soils of the sandplain, overlying Permian lateritic-rich plains.

Distribution: This rare species is endemic to the Byro-Mt Narryer area of Western Australia. 
Conservation Status: The Rangeland Survey Team of the Department of Agriculture, Western Australia, have located this species on the Byro, Curbur, Mt Narryer and Muggon pastoral properties (Ray Cranfield pers. comm., 10 June 1991). Its distribution reflects the very geographically restricted interzone of Permian and wash plains, which only occurs on three or four properties in this area (P. Curry in Cranfield pers. comm., 6 September 1991). Therefore the species is confined to an area of about $300 \mathrm{~km}^{2}$. Although the distribution of this species is restricted, the known populations contain several hundred plants, with seedlings reported as either very common (Conn 2083, Conn 2091-2096 and Cranfield pers. comm., 10 June 1991) or none seen (P. Curry in Cranfield pers. comm., 6 September 1991). Irrespective of the number of seedlings, the percentage that mature in this harsh environment may be very low, particularly because it is heavily grazed by stock and kangaroos.

Although more information about the distribution of this species is now available, the Western Australian Department of Conservation and Land Management consider it to be a 'Priority 1 ' species. That is, a species under immediate threat and under consideration for declaration as rare flora, but in need of urgent high priority further survey. Therefore, the risk code of $2 \mathrm{~K}$ (applied by Briggs \& Leigh 1988) should be changed to $2 \mathrm{~V}$.

Other specimens examined: Western Australia: Austin: 'Upper Murchison R. [River]', I. Tyson 4, 1892 (MEL 41916); Byro Station, c. 28 km NW of Mullewa-Gascoyne Junction Road, on road to Woodleigh Station, Conn 2083, 11 Sep 1985 (MEL, PERTH), Conn 2091, 12 Sep 1985, (AD, CANB, MEL, PERTH), Conn 2092 [this and all following specimens collected on same day as Conn 2091 ](BRI, MEL, PERTH), Conn 2093 (MEL, PERTH), Conn 2094 (MEL, NSW, PERTH, RSA), Conn 2095 (CANB, MEL, PERTH), Conn 2096 (AD, CHR, MEL, MO, PERTH), Conn 2098 (CANB, MEL, NSW, PERTH), Cranfield 5162, 21 June 1985 (PERTH); Curbur Station, Payne 107, 31 Oct 1985 (PERTH), Payne 126, Oct 1985 (PERTH).

\section{Acknowledgments}

Mr Ray Cranfield (PERTH) provided additional distribution information, incorporating data obtained by the Rangeland Survey Team (Department of Agriculture, Western Australia) and information from the Western Australian Department of Conservation and Land Management. This study was supported by an Australian Biological Resources Study Grant.

\section{References}

Bentham, G. \& Hooker, J.D. (1876) Genera plantarum, vol. 2 (Reeve: London).

Briggs, J.D. \& Leigh, J.H. (1988) Rare or threatened Australian plants - 1988 revised edn. Austral. Natl. Parks \& Wildlife Service Special Publication no. 14.

Briquet, J. (1895) Labiatae p.p. Pp. 183-221 in Engler, A. \& K. Prantl (eds), Die Natürlichen Pflanzenfamilien, Teil IV, Abteilung 3a (Engelmann: Leipzig).

Carrick, J. (1977) Studies in Australian Lamiaceae 2. Eichlerago, a new genus allied to Prostanthera. J. Adelaide Bot. Gard. 1: 115-122.

Conn, B.J. (1984) A taxonomic revision of Prostanthera section Klanderia (F.v. Muell.) Benth. (Labiatae). J. Adelaide Bot. Gard. 6: 207-348.

Conn, B.J. (in press) Relationships within the tribe Prostanthereae (Labiatae). In Harley, R.M. \& Reynolds, T. (eds). Advances in Labiate Science (Royal Bot. Gard., Kew: London).

Sharma, M. \& Singh, V. (1982) Morphology of the gynoecium in Labiatae. Blumea 28: 61-75. 